\title{
The Determinants of Shareholder Value in Retail Banking During Crisis Years: The Case of Greece
}

\author{
Eleftherios Aggelopoulos* \\ University of Patras, Greece \\ Antonios Georgopoulos \\ University of Patras, Greece
}

This study examines the performance of retail banking focusing on the link between shareholder value creation and operational value drivers. A unique panel data set is used, derived from the monthly Profit and Loss statements of a branch network of a very large commercial bank operating in the Greek oligopolistic financial system for the period 2006-2010. Taking into account the existence of important trade-offs between most factors of shareholder value, the value effects of the recent Greek crisis primarily characterized by the sovereign debt factor are systematically incorporated in the analysis. The results show that the crisis reverses the generally positive value effect of income diversification and reduces the value premium of lending spreads. Moreover, the crisis significantly intensifies the value premium of efficient cost management, whilst simultaneously accelerating the value destruction causing by credit risk. The findings have important managerial implications for bank managers and policymakers. (JEL: G21, G32, M41, C23)

Keywords: retail banking performance, shareholder value drivers, residual income approach, Greek crisis

Article history: Received: 30 April 2014, Received in final revised form: 27 February 2015, Accepted: 05 March 2015, Available online: 13 May 2015

\footnotetext{
* The authors would like to thank participants of the Conference on Banking, Finance, Money and Institutions: The Post Crisis Era (2-3 November 2013, University of Surrey, UK) and the Multinational Finance Society Symposium (4-5 April 2014, Municipal Art Gallery, Larnaca, Cyprus), for very helpful comments.
}

(Multinational Finance Journal, 2015, vol. 19, no. 2, pp. 109-147)

(C) Multinational Finance Society, a nonprofit corporation. All rights reserved. DOI: $10.17578 / 19-2-2$ 


\section{Introduction}

Banking performance and its determinants is an interesting issue in the banking management literature. A major part of the relevant literature focuses on productive efficiency, total factor productivity and profitability of banking institutions (Athanasoglou, Brissimis and Delis, 2008; Brissimis, Delis and Papanikolaou, 2008; Lepetit et al., 2008; Goddard, Molyneux and Wilson, 2004; Salas and Saurina, 2003). Unexpectedly, only few studies have ever used Shareholder Value (SHV) creation as bank performance indicator (Cipollini and Fiordelisi, 2012, Fiordelisi and Molyneux, 2010, 2007; Fiordelisi, 2007; Gross, 2006), despite its main strategic importance for banks over the last decade (Fiordelisi and Molyneux, 2010) and its positive impact on their risk reduction (Cipollini and Fiordelisi, 2012). The recent financial crisis has made the banking performance analysis and the creation conditions of SHV, in particular, more interesting. This is because the involvement of banks in the crisis has differentiated considerably across crisis countries.

From this point of view, the Greek crisis ${ }^{1}$, which originated from the sovereign debt crisis in the country, is investigated while the domestic banking sector remained relatively sound since indigenous banks focused on retail commercial activity and not on investment banking which caused huge marked to market losses related to toxic assets. In other words, the crisis did not hit the country because of a risky banking sector (as, for example, in Ireland), but because of the sovereign factor. Therefore, this study explores the crisis effects on the SHV drivers in a turbulent economic environment in which banking institutions were not the primary cause of the crisis.

The present study proposes that SHV creation is not a straightforward phenomenon and important trade-offs between most factors of SHV exist. In light of the occurrence of the crisis and its unique features, the paper derives interesting implications for banking management itself, credit provision and the real economy, in the sense that an efficient and well functioning banking system accelerates long term economic growth (Kaufman, 2004). In particular, the SHV determinants are examined, concentrating on retail banking over the

1. The Greek debt crisis, being part of the Euro zone crisis, was triggered by the arrival of the recent financial crisis. The financial crisis that started at the end of 2007 in the subprime credit market led to a liquidity crisis in the short term money markets (Iqbal and Kumel, 2014) and increased the domestic deposit rates in September 2008. 
period 2006-2010. Moreover, the total period is divided into the pre crisis period (Period A: January 2006-August 2008) and the crisis period (Period B: September 2008-December 2010) in order to capture specific crisis effects. An internal bank data set is utilized, derived from the monthly Profit and Loss (P\&L) statements of homogeneous retail branches of a very large domestic bank (one of the four largest systemic Greek commercial banks). In this way, the data set can ensure two crucial conditions. Firstly, value driver analysis at the bottom-level requires a high degree of sample homogeneity. Secondly, a research design in retail banking performance should be based on internal data of bank branches of a specific banking institution and not be performed across competing banking institutions (since the definition of the retail segment considerably varies across banks). The oligopolistic and homogeneous financial environment in which the case study bank operates, with it's specialization in commercial banking; mainly retail banking, can guarantee, without doubt, a generalization of the results.

A fixed-effects model specification is applied to the panel of retail branches which produces efficient estimates and different robustness checks are run (Generalized Method of Moments - GMM estimator, Two-Stage Least Squares - TSLS estimator) to account for persistence of the dependent variable and potential endogeneity of regressors. The creation of SHV is measured by the Residual Income (thus, RI is our dependent variable), which is an effective instrument of value creation measurement at the bottom level (Garvey and Milbourn, 2000), and as to the explanatory variables four branch specific operational value drivers are included such as income diversification, cost management, credit risk taking and lending spreads following other SHV studies (Cipollini and Fiordelisi, 2012; Fiordelisi and Molyneux, 2010).

The results suggest some interesting relationships between bank SHV creation and the four value drivers included in the analysis. Overall, the findings indicate that the current crisis effects might have an ambiguous impact on SHV. More specifically, the crisis reverses the positive SHV effect of diversification in the expansion period to a negative effect. So an adoption of a diversified business mix strategy during the crisis seems to destroy value. Likewise, the crisis reduces the positive SHV impact on branches which lend with high margins, indicating excessive relaxation of lending standards during the expansion period. Moreover, the crisis increases the positive value effect of operationally cost efficient branches, so the adoption of branch rationalization measures might help to create value in crisis years. Finally, loan loss impairments significantly increased during the crisis, 
and this is reflected in the extra negative impact of credit risk taking on SHV during that period. The results confirm all the research hypotheses.

The main contributions of this study are as follows. First, the paper offers new evidence on the bulk of the currently uninvestigated field of SHV creation in a dynamic environment, as it is expressed from the passage of the expansion period to the crisis period. Indeed, the on-going serious crisis in the Greek economy stimulates research interest as it is very likely that the crisis will reduce a generally expected value premium or even cause it's disappearance, in turn causing value destruction. More specifically, the study provides useful information about the quality of banking performance at the retail level in the "bank-driven" crisis economy of Greece which is characterized by sovereign debt and a relatively weak local financial market, as well as other Mediterranean economies of the European region (e.g. Italy, Portugal, and Spain). In this way, this might offer useful lessons for those specific countries as well. Second, the study sheds light on the sources of value creation in retail banking, which is largely unexplored due to the lack of primary data at bank branch level. This becomes even more important since most of the research in retail banking performance is applied to small branch populations, e.g., fewer than 50 branches, and deals with branch efficiency and no value creation (Deville, 2009). Third, the bottom level field research that is applied, guarantees that value creation and value destruction can be measured directly at their sources by also capturing the direct crisis effects immediately. Finally, the utilization of a unique data set in the study allows fixed-effects to be used at the branch and month level and this covers a lot of ground in terms of identification.

The results have various implications for both bank management and policymakers. Bank policy should be more flexible due to changing external conditions. Also, it should adopt a more proactive way of "thinking" about the implications of an economic change, which are manifested in the transition from the expansion to the crisis period and vice versa. Under such conditions bank policy should be different when moving from one economic period to another. The findings support post-crisis initiatives taken at the European level as regards the managing of credit risk and the proactive and countercyclical policy. Also, they suggest specific actions that should be introduced, both at the bank and the institutional level in order to reduce exogenous shocks to the banking industry.

The rest of the study is organized as follows. Section II reviews the existing literature on SHV and presents the value creation process in 
retail banking along with the crisis effects. Section III defines $R I$, identifies the beginning of crisis and presents the data description. Section IV describes the methodology employed to construct the model and the alternative models. Section V illustrates the empirical results and the last section discusses the main findings and proposes policy implications.

\section{Theoretical background and hypotheses}

This section presents the relevant literature on SHV determinants and the theoretical framework of value creation process in retail banking along with the development of research hypotheses.

\section{A. Literature on determinants of shareholder value}

There is a large amount of literature exploring how banks are able to increase their performance and profitability. Studies like Dietrich and Wanzenried (2011), Athanasoglou, Brissimis and Delis (2008), Brissimis, Delis and Papanikolaou (2008), Lepetit et. al. (2008), Berger and Mester (2003), Salas and Saurina (2003) consider a wide range of bank-, industry- and macro-specific variables that may have an impact on banking profitability. Their empirical results vary due to differences in their panel datasets, time periods and sample countries. However the empirical literature on SHV determinants is relatively scarce. In particular, Fiordelisi (2007) and Beccalli, Casu and Girardone (2006) primarily connect a single value factor with SHV creation instead of utilizing a set of different value SHV drivers. Fiordelisi and Molyneux (2010), examining several bank- and industry- and macroeconomic-specific determinants of SHV creation for a large sample of European banks between 1998 and 2005, emphasize that such value factors often have both positive and negative effects on SHV creation. Their most important finding is that income diversification, cost and revenue efficiency are shown to have a positive relationship on SHV, whereas a corresponding positive relationship between credit risk taking and SHV confirms the good luck hypothesis - as banks take on more credit risk they also boost their interest revenues. Similarly, Gross (2006) examines determinants of SHV creation such as income diversification, cost management, credit risk taking and branch structure, for a sample of 139 retail banks in Germany in the period 1998-2003. The findings suggest that only cost management and credit 
risk taking are significant drivers for SHV in banks in the sense that an increase in credit risk taking destroys value while an increase in cost efficiency creates it.

To the best of our knowledge, no previous study has investigated the recent crisis impact on SHV determinants although a few studies investigate the crisis impact on bank profitability in general (Dietrich and Wanzenried, 2011; Xiao, 2009). More specifically, Dietrich and Wanzenried (2011) analyze four profitability determinants (cost efficiency, income diversification, growth of total loans and funding costs) of 372 commercial banks in Switzerland. They consider separately the pre-crisis period (1999-2006) and the crisis years (2007-2009). They find that income diversification and cost efficiency boost bank profitability in both periods, whereas the profitability effect of credit risk taking is negative and significant, only in the crisis period.

Finally, the literature on performance and profitability determinants of the Greek banking sector is generally scarce (Athanasoglou, Brissimis and Delis, 2008; Eichengreen and Gibson, 2001). In an important contribution, Athanasoglou, Brissimis and Delis (2008) test whether bank-, industry- and sector-specific variables influence the profitability of the Greek banking sector from 1985-2001. The authors provide inter alia evidence that credit risk taking and high operating expenses are both negatively and significantly related to bank profitability. Eichengreen and Gibson (2001) state that the effect of staff expenses is positive and significant, possibly due to quality effect (human capital). Thus, no study until now has analyzed the SHV determinants of the Greek retail banking and indeed in the recent crisis period.

\section{B. The value creation process in retail banking}

A bank creates value for its shareholders when the return on invested capital is greater than its opportunity cost. A common measure of a bank's SHV creation is $R I^{2}$. $R I$ can be calculated for the bank as a whole (i.e. difference between bank's net operating profit and cost of equity employed) but when used as a basis to measure the performance of retail branches, then the earnings and amount of equity allocated to these branches must be identified, so their $R I$ can be calculated. Thus, $R I$ for each bank branch (Dermine, 2009; Feltham and Ohlson, 1995)

2. The RI model and other SHV models such as Economic Value Added (EVA) and Economic Profit (EP) are identical in practice. 


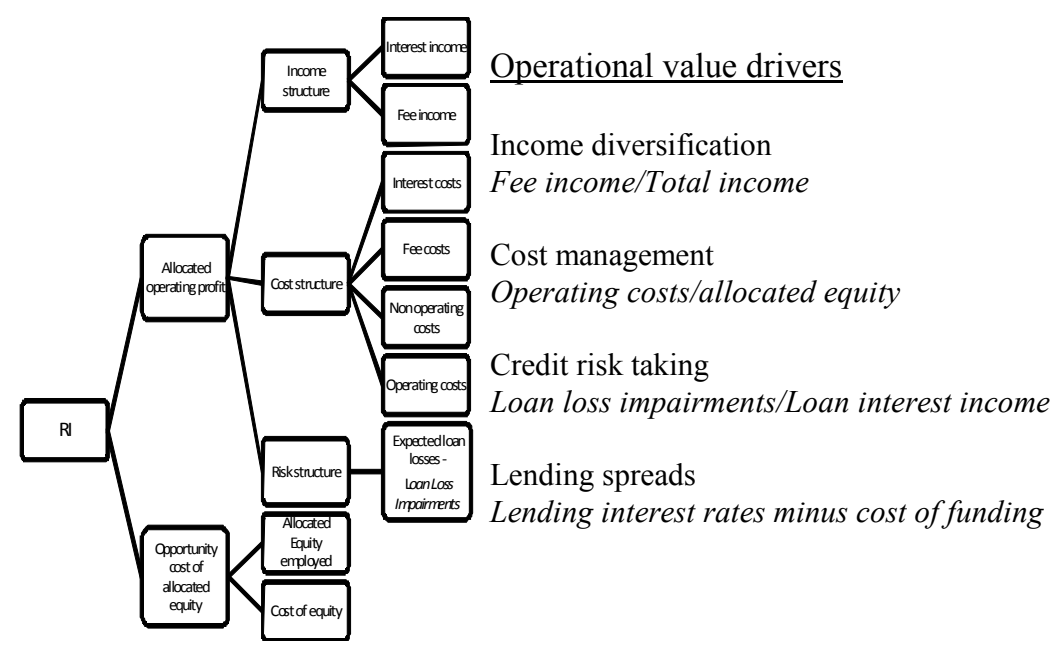

FIGURE 1.- The relationship between RI and the different drivers (Fiordelisi and Molyneux 2010, Gross, 2006, own contribution).

Note: Residual income (RI) for each branch is calculated as the difference between the allocated net operating profit and the opportunity cost of allocated equity, i.e. the product of allocated equity and cost of equity. The bank management needs to put actions in place to increase the operating profit and/or reduce the equity employed and the cost of equity. The allocation of income to the branches is implemented through the concept of fund transfer pricing that allows interest income from lending and deposit transactions to be calculated in isolation for each branch (Kimball, 1998). The operating profit is related to the income, cost and risk structure of a branch. The income structure contains interest income from lending and deposit transactions and fee income. The cost structure includes interest costs, fee costs, operating and non-operating expenses. The risk structure contains the expected loan losses (i.e. loan loss impairments). As regards the allocation of equity to each branch, this is obtained by applying the capital requirements for retail exposures, against credit and operational risk (Basel II rules through risk weighted assets - RWA). Equity employed can be reduced directly by decreasing loan balances or diversifying income, while the cost of equity maybe reduced indirectly by reducing risk exposure or improving risk management.

is calculated as the difference between the allocated net operating profit and the cost of allocated equity, i.e. the product of allocated equity and cost of equity.

According to Fiordelisi and Molyneux (2010), the bank management has three buttons to push to affect the $R I$, which are; net operating profit, equity employed and the cost of equity. Specifically, a bank needs to put actions in place to increase the net operating profit and/or reduce the equity employed and the cost of equity (i.e. reduce capital charges). These structures depend on branch specific value drivers. The relationship between $R I$ and the value drivers can be observed in figure 
1. From this value driver tree, different drivers can be evaluated. Based on earlier profitability (Berger and Mester, 2003; Lepetit et al., 2008; Beccalli, Casu and Girardone, 2006) and shareholder value (Fiordelisi and Molyneux, 2010; Gross, 2006) literature, we suggest that actions such as income diversification, efficient operating expenses management and credit risk taking are expected to have an interesting impact on $R I$. Also, granting loans with a high spread is considered a valuable driver (Dermine, 2009) for the income structure of the branch.

The value created for shareholders is the final result of the process and it can be safely assessed by considering only two issues: The trade-off between the above value drivers in the sense that they might have both a positive and a negative effect on SHV (affecting at the same time various components of it, such as the income, cost and risk structure). It is the net effect that will determine whether any action is value enhancing. From this point of view, it is important to also examine the crisis impact on SHV, as compared to the growth period. The crisis might hamper the dynamic of the SHV creation process. Hence, the net value effect will finally show the overall contribution of the value determinants.

In the following section the research hypotheses are formed for each value driver.

\section{The impact of the crisis on the value creation process in retail banking}

Income diversification ( $I D$, i.e. is the ratio of fee income to total income) may positively influence bank performance and SHV due to several reasons. In particular, income diversification provides more stability of income as service fees are uncorrelated with net interest income. It also offers higher profitability since margins in fee income are usually higher than margins in interest operations. This reduces risk because there is no credit risk in fee income and implies less capital charges as there are no capital requirements for credit risk (just operational risk). Empirical studies stress the expected benefits of diversification in the banking industry (Cipollini and Fiordelisi, 2012; Fiordelisi and Molyneux, 2010; Dietrich and Wanzenried, 2010). Nevertheless, a relatively high share of non-interest income can create less value through increased costs, as branches are charged with relatively high operating costs related to the offering and monitoring of 
these services (Lepetit et al., 2008; Gross 2006; Demirguk-Kunt and Huizinga, 1999). Under these circumstances, branches might fail to achieve economies of specialization and probably waste valuable resources in peripheral activities. Hence, in the crisis period, bank branches might focus on their main business activity due to rationalization requirements (restructuring loan portfolio, increase collection performance of loan accounts, etc.). Consequently a high diversification policy may not be appropriate nor fully effective and could destroy value during crisis years. Therefore, the hypothesis below is formed:

\section{H-1. The crisis reduces the generally expected value premium of diversification.}

The level of operating expenses management (COST i.e. is the ratio of controllable operating expenses to equity employed) in terms of relative high operating expenses (i.e. inefficient cost management) can be negatively related to SHV, in particular in the case, where personnel expenses are affected by relatively low productivity (Athanasoglou, Brissimis and Delis, 2008). In such a case there is a lack of efficiency in total controllable costs and branches try to pass part of the increased cost to customers. Empirical evidence supports the theoretical premise that improved management of these expenses will increase efficiency and therefore create value (Fiordelisi and Molyneux, 2010; Dietrich and Wanzenried, 2010; Athanasoglou, Brissimis and Delis, 2008; Gross 2006). However, "aggressive" efficiency programs may lead to reduced customer satisfaction and staff quality (Fiordelisi and Molyneux, 2010). This policy may have an adverse impact on workforce motivation or increase risk caused by substantial deterioration of service quality. This may be true since retail banking is a relatively labor-intensive industry where the physical contact with the customer constitutes an important competition factor. In addition, excessive cost saving efforts may negatively affect the ability of a bank to screen loans so that the ensuing loan losses outweigh the initial cost savings (Andreou, Philip and Robejsek, 2013). This argument is consistent with the "cost skimping" hypothesis which posits a trade-off between short term operating costs and future risk taking (Fiordelisi, Marquez-Ibanez and Molyneux, 2011; Berger and Young, 1997). All aforementioned factors may adversely affect value creation through reduced income or increased risk 
(Fiordelisi and Molyneux, 2010, 2007; Garcia-Herrero, Gavila and Santabarbara, 2009). Especially in the crisis period, it is expected that branches are probably focused on reducing operating costs through salary freezes and staff retrenchments, thus accelerating branch rationalization to offset the decrease in profit due to falling demand for new loans (Demirguk-Kunt, Detragiache and Gupta, 2006). Therefore, the hypothesis below is formed:

\section{H-2: The crisis increases the generally expected value premium of efficient cost management.}

The effect of higher credit risk taking ( $C R$, i.e. is the ratio of total loan loss impairments to net interest income on loans) on performance is expected to be negative because of the relative rise of loan impairments, as reported on branch $\mathrm{P} \& \mathrm{~L}$ statements. This negative effect is supported by empirical studies (Athanasoglou, Brissimis and Delis, 2008; Brissimis, Delis and Papanikolaou, 2008; Gross, 2006; Miller and Noulas, 1997). In contrast, the "good luck" hypothesis (Fiordelisi, Marquez-Ibanez and Molyneux, 2011; Salas and Saurina, 2003) suggests that credit risk taking which involves lending to customers with low credit score, at high rates of interest might increase the loan volumes and thus the ability of the institution to generate interest income through market share expansion. Fiordelisi and Molyneux (2010) provide empirical evidence of the "good luck" hypothesis. However, this policy might be more appropriate for the period of economic growth, especially for followers in the market who try to catch up with the market leader usually at the expense of the quality of lending standards. In the crisis period, the relative significant rise of loan loss impairments is normally connected with lower credit risk capabilities due to the unfavorable economic environment. Therefore, in this period, we expect an extra negative impact of credit risk taking on SHV. Taking into account the above considerations, the hypothesis below is formed:

\section{H-3: The crisis increases the generally expected destructive value effect of credit risk taking.}

Regarding the profitability spread derived from lending business (SPREAD, i.e. is the difference between contractual lending interest rates and cost of funding), it is expected that retail branches which charge higher lending spreads to their lending customers naturally 


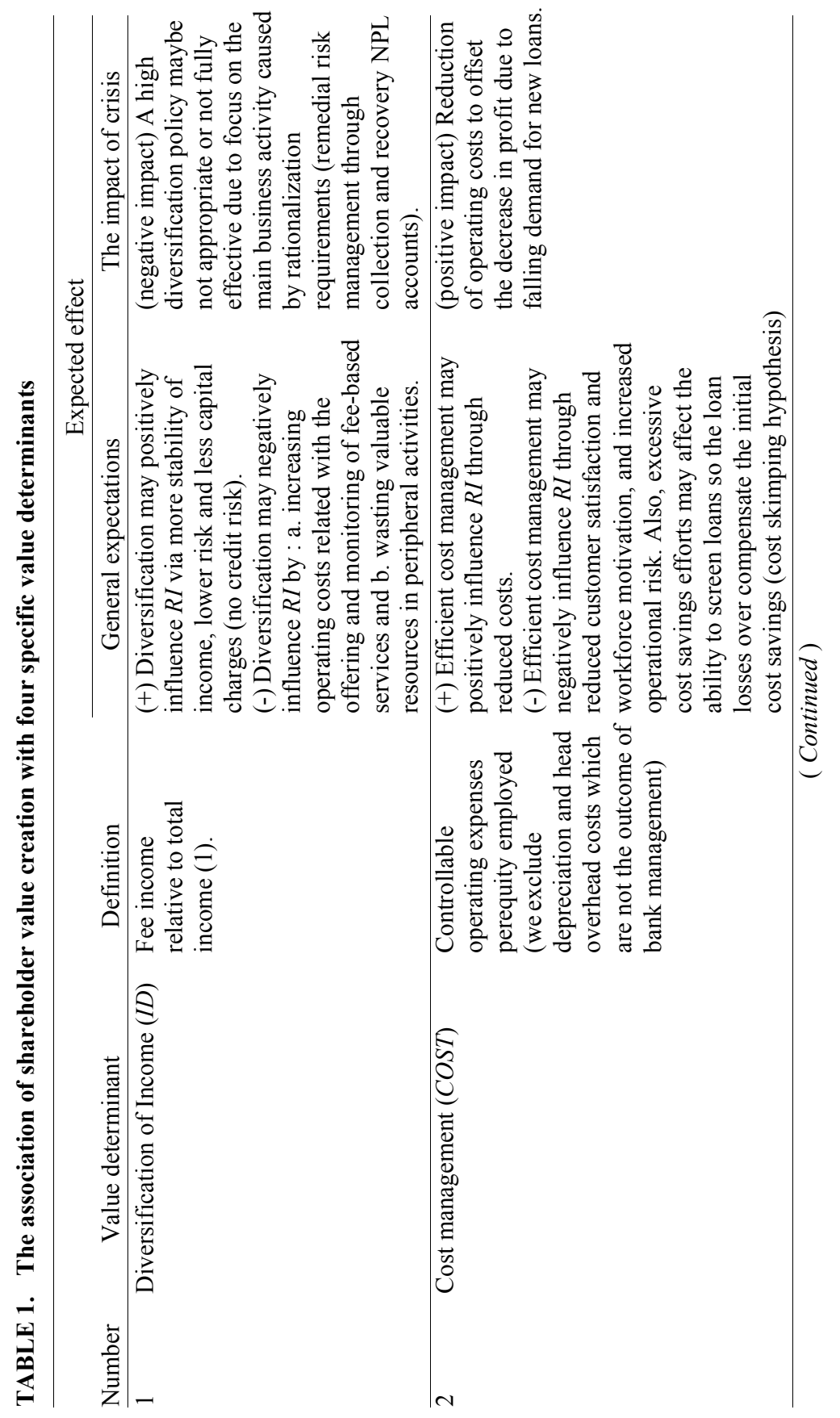




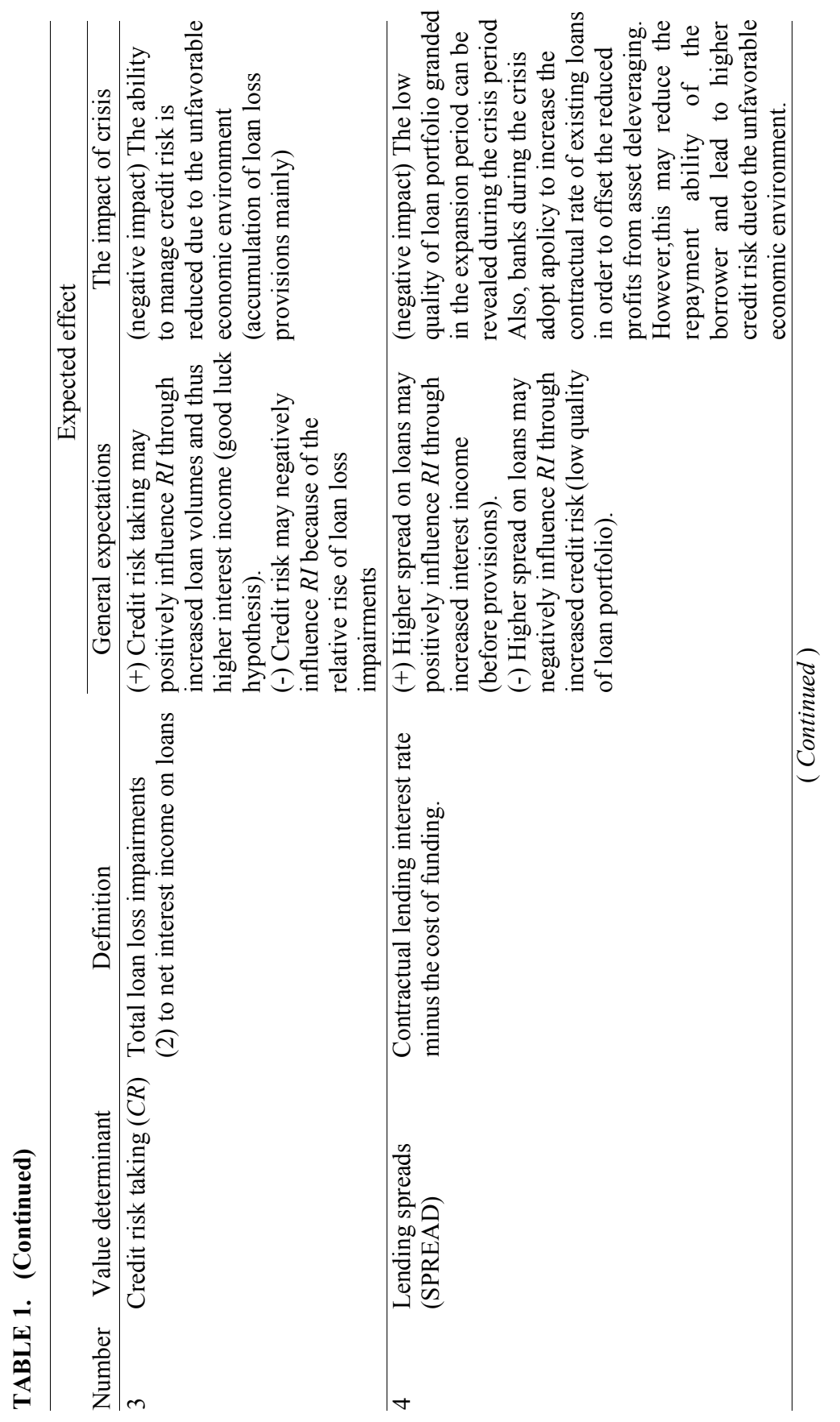




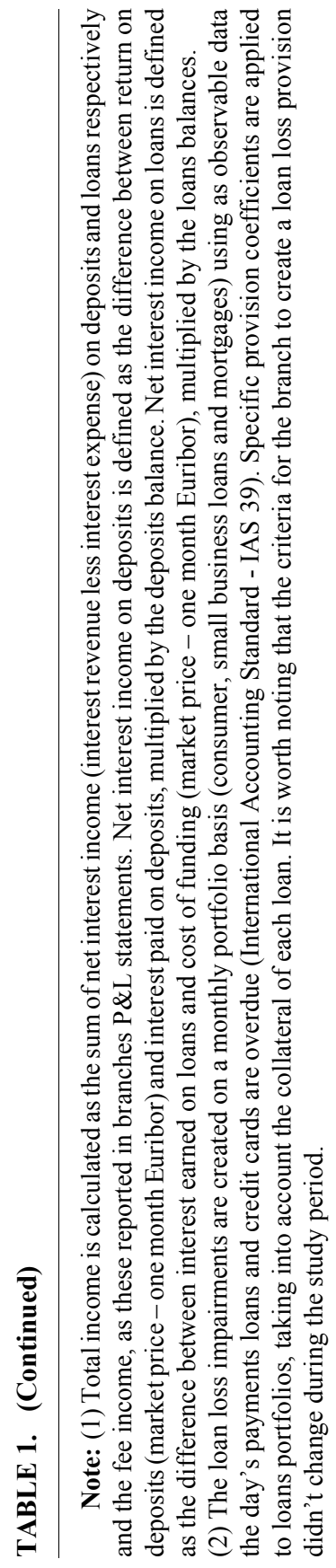


present a higher value due to increased interest income (Dermine, 2010; 2009). However, high interest margins maybe hide a relatively low quality loan portfolio with negative impact on SHV creation since the credit risk is priced and included in the contractual interest rate paid by the borrower. In the period of crisis, such loan portfolios are usually related to higher credit risk, with destructive impact on SHV. Moreover, during crisis periods the bank management attempts to increase the contractual rate of existing loans in terms of a repricing policy as an offset to the asset deleveraging (that takes place in a crisis period) which leads to lower loan volumes and interest income. But, this policy might have side effects via the reduction of repayment ability of the borrower and the increase of loan loss impairments due to the unfavorable economic environment. Taking into account the above considerations, the hypothesis below is formed:

H-4: The crisis reduces the generally expected value premium of lending spreads.

Table 1 summarizes the association of SHV measured by $R I$ with the aforementioned four determinants by analyzing the definition of each determinant and the expected effect on $R I$.

\section{Variables and data description}

This section describes the definition of $R I$ and presents the data itself along with the identification of crisis.

\section{A. Definition of Residual Income}

As described above, the $R I$ is used as a proxy for the SHV creation of the sample retail branches. $R I$ is defined as net operating profit less a capital charge for the equity employed. $R I$ is calculated as follows (Gross, 2006):

$$
R I_{i t}=N O P A T_{i t}-E_{i, t / t-1} * c_{e, t}
$$

where: $R I_{i t}$ is the residual income of bank branch $i$ in month $t ; N O P A T_{i t}$ is the net operating profit after taxes of branch $i$ in month $t ; c_{e, t}$ denotes the cost of equity of bank in month $t ; E_{i, t t-1}$ denotes the average equity of bank branch $i$ in month $t$ and $t-1$. 
Net operating profit after taxes is calculated as the difference between the total income and the sum of total costs, total loan loss impairments and taxes. The equity employed by each branch is obtained by applying the capital requirements for retail exposures, against credit ${ }^{3}$ and operational risk ${ }^{4}$ (Basel II via Bank of Greece - BOG - Governor's Act: No 2588 \& No 2590, 20.08.2007). Regarding the cost of equity at the retail branch, it is approximated with the overall cost of equity of the bank (Dermine, 2009; Gross, 2006). The bank's cost of equity capital is calculated looking at the shareholders expected rate of return that is estimated by using the Capital Asset Pricing Model (CAPM) framework, adjusted for default risk (Damodaran, 2012, 2010; Fernandez, Aquirreamalloa and Avendapo, 2011). This method is the most widely theoretical approach in empirical research (Fiordelisi and Molyneux, 2010, 2007) and the preferred method in the context of valuing banks in most of the literature (Damodaran, 2009; Dermine, 2009). The empirical results (listed below) were tested for their robustness and sensitivity to changes in the value of the cost of equity.

\section{B. Data and Crisis identification}

The original data set is derived from a branch network of a major commercial bank (370 branches in total) spread across Greece for the period January 2006 to December 2010. The end-month P\&L statements of these branches are used, obtained from the Management Information System of the bank of the study. The unique data set is utilized in two ways: Firstly, the criterion of strict homogeneity of selected branches is applied, in terms of: services provided (to individuals, micro and small-sized enterprises ${ }^{5}$ ); size (specific loan and deposit volumes ${ }^{6}$ );

3. The capital requirement for credit risk is calculated by the sum of the risk weighted loans of each branch (weight $75 \%$ for mortgages, consumer, small business loans and credit cards), multiplied with the Basel capital ratio $8 \%$.

4. The capital requirement for operational risk is calculated by multiplying the operating income before taxes and loan provisions, with $12 \%$

5. These entities are the most important clients for the Greek banks (pure retail banking). In this category the total retail exposure of individuals, microenterprises and small-sized enterprises is less than 1 million Euros, whereas each enterprise has a maximum turnover of 2.5 million Euros.

6. The study focuses on branches that presented loan and deposit volumes in January 2006 ranging between 20 million and 80 million and 20 million and 60 million respectively. 
branch age establishment ${ }^{7}$ and branch location (branches placed in urban $\operatorname{areas}^{8}$ ). This leads to a wide, homogeneous sample of 117 retail branches of the specific bank, symmetrically dispersed across Greece. Secondly, the criterion of strict homogeneity is relaxed and the total branch network is analyzed, taking into account some specific branch characteristics such as the branch size, the branch location and the branch ability to use its own deposits to make loans. As regards the branch size, three branch groups are formed given the deposit balances: small-sized branches with a 5 year average total deposit balances between 5 to 20 million Euros ( 25 branches), medium-sized branches with a 5 year average total deposit balances between 20 to 60 million Euros (121 branches) and large-sized branches with a 5 year average deposit balances of more than 60 million Euros (123 branches). As regards the location of branches, the branches are separated into three categories: branches operating in urban areas (102 branches), branches operating in rural areas ( 80 branches) and finally branches operating on islands (31 branches). Finally, as regards the ability of each branch to use its own deposits to make loans, according to its 5 year average loan to deposits ratio, three groups are analyzed: branches with a loan to deposit ratio of less than $90 \%$ ( 67 branches), branches with a loan to deposit ratio between $90 \%$ to $120 \%$ (59 branches) and finally branches with a loan to deposit ratio of more than $120 \%$ (95 branches). In all cases, the dataset includes branches that were in operation for more than two years (year of establishment before 2004) and that have achieved the operational breakeven point (e.g. presenting a positive pre provision profit in January 2006).

Next the beginning of the crisis is determined, in order to contrast the expansion period to crisis period. To identify the exact point at which the crisis begins, which is crucial for the validity of empirical results (Kenourgios, Christopoulos and Dimitriou, 2013), the interest rate of time deposits is used as an indicator. This is owing to the fact that they are substantial in volume and price sensitive, with the result that any liquidity shortage in the market is reflected directly in their cost. The average interest rates of time deposits for Greek banks

7. The study focuses on branches that have been operating for more than five years and less than fifteen years, using 2006 as a base year. This is crucial since the branch age influences the calculation of loan loss impairments and by extension the quality of branch loans portfolio.

8. Branches that operate in rural areas and on islands are affected by seasonality. 


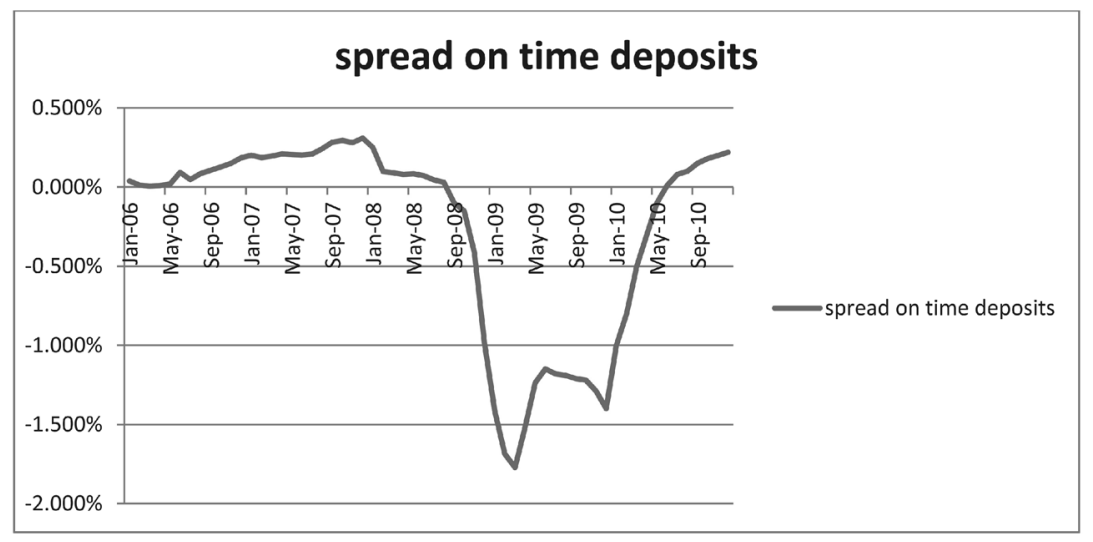

FIGURE 2.- The development of monthly average spread of time deposits (difference between return on time deposits and interest paid on them) for the total branch network, over January 2006 to December 2010.

Note: A notably change can be observed in the trend after mid September 2008. Moreover, this structural point is econometrically derived from the time series of the specific deposits over the total period of the study, by applying the minimum Lagrange Multiplier (LM) unit root test proposed by Lee and Strazicich (2003).

increased markedly in September 2008 (BOG, 2009) from 4.99\% (August 2008) to 5.11\% with an increasing trend until the end of December 2008, where the month rate was $5.36 \%$. Also, the beginning of the financial crisis at the same point of time is endogenously confirmed, based on the total branch network. Figure 2 illustrates the development of the monthly average spread of time deposits (difference between return on time deposits and interest paid on them) for the retail branches, over the period from January 2006 to December 2010. A notable change can be observed in the trend after mid September 2008. Moreover, this structural point is econometrically derived from the time series of the specific deposits over the total period of the study, by applying the minimum Lagrange Multiplier(LM) unit root test proposed by Lee and Strazicich (2003). Lee and Strazicich's model shows that the structural break point in the trend of the specific deposits takes place in September 2008 (minimized LM unit root t-statistic: -16.707 computed by using the Gauss programming codes).

Given that the dependent variable is directly linked to a "value", measure, some evidence concerning the economic significance of the 
TABLE 2. Statistics of the Greek economy over the period 2007 to 2010

\begin{tabular}{|c|c|c|c|c|}
\hline Variable & 2007 & 2008 & 2009 & 2010 \\
\hline Real GDP growth $(\%)$ & $3.5 \%$ & $-0.2 \%$ & $-3.2 \%$ & $-4.9 \%$ \\
\hline $\begin{array}{l}\text { Fiscal deficit- general government } \\
\text { balance ( } \% \text { of GDP) }\end{array}$ & $6.5 \%$ & $9.8 \%$ & $15.7 \%$ & $10.7 \%$ \\
\hline $\begin{array}{l}\text { Fiscal deficit-primary balance } \\
(\% \text { of GDP) }\end{array}$ & $2.0 \%$ & $4.8 \%$ & $10.5 \%$ & $4.9 \%$ \\
\hline Gross Debt $(\%$ of GDP $)$ & $107.4 \%$ & $112.9 \%$ & $129.7 \%$ & $148.3 \%$ \\
\hline $\begin{array}{l}\text { Coincident indicator of economic } \\
\text { activity (points) }\end{array}$ & 100 & 68 & 40 & 35 \\
\hline NPL ratio of banking sector $(\%)$ & $4.5 \%$ & $5.0 \%$ & $7.7 \%$ & $10.4 \%$ \\
\hline
\end{tabular}

Note: This table presents the macroeconomic environment in Greece before and during the crisis (Bank of Greece-BOG-, 2014; 2010; 2009)

change in the Greek economy for the period 2007-2010 are presented in table 2. This table reveals that Greece recorded its worst economic performance in 2009 since joining the euro area. The Gross Domestic Product(GDP) after fifteen years of continuous growth declined in 2008 by $0.2 \%, 3.2 \%$ in 2009 and $4.9 \%$ in 2010 . Due to the huge fiscal expansion in 2009 , the general government deficit this specific year reached $15.7 \%$ of GDP (9.8\% of GDP in 2008) and the primary deficit to $10.5 \%$ of GDP $(4.8 \%$ of GDP in 2008$)$. As a result, the gross debt as a percentage of GDP increased from $112.9 \%$ in 2008 to $129.7 \%$ in 2009 and reached $148.3 \%$ in 2010 (BOG, 2014). In light of the rapid worsening of the fiscal situation in Greece, financial markets and rating agencies turned their attention to the sustainability of Greece's fiscal and external imbalances. This led to a downgrading of the creditworthiness of the Greek economy in October 2009 and a significant widening of the yield spread between Greek and German bonds (BOG, 2010). The deteriotion of the macroeconomic enviroment was also reflected in the coincident indicator of economic activity which records the expectations of Greek enterprices and households, compiled by the Bank of Greece. The specific indicator decreased by 28 points between 2008 and 2009 (2009: 68 points , 2009: 40 basis points) and then dropped further to 35 points in March 2010 (BOG, 2010). This adverse environment negatively affected the financial condition of households and non financial corporations, thus increasing the number of non-performing loans (NPL) of the banking sector. The overall NPL ratio of Greek banks rose to $7.7 \%$ in 2009, from $5.0 \%$ in 2008 and more than doubled in 2010 from its 2008 levels, to $10.4 \%$. 


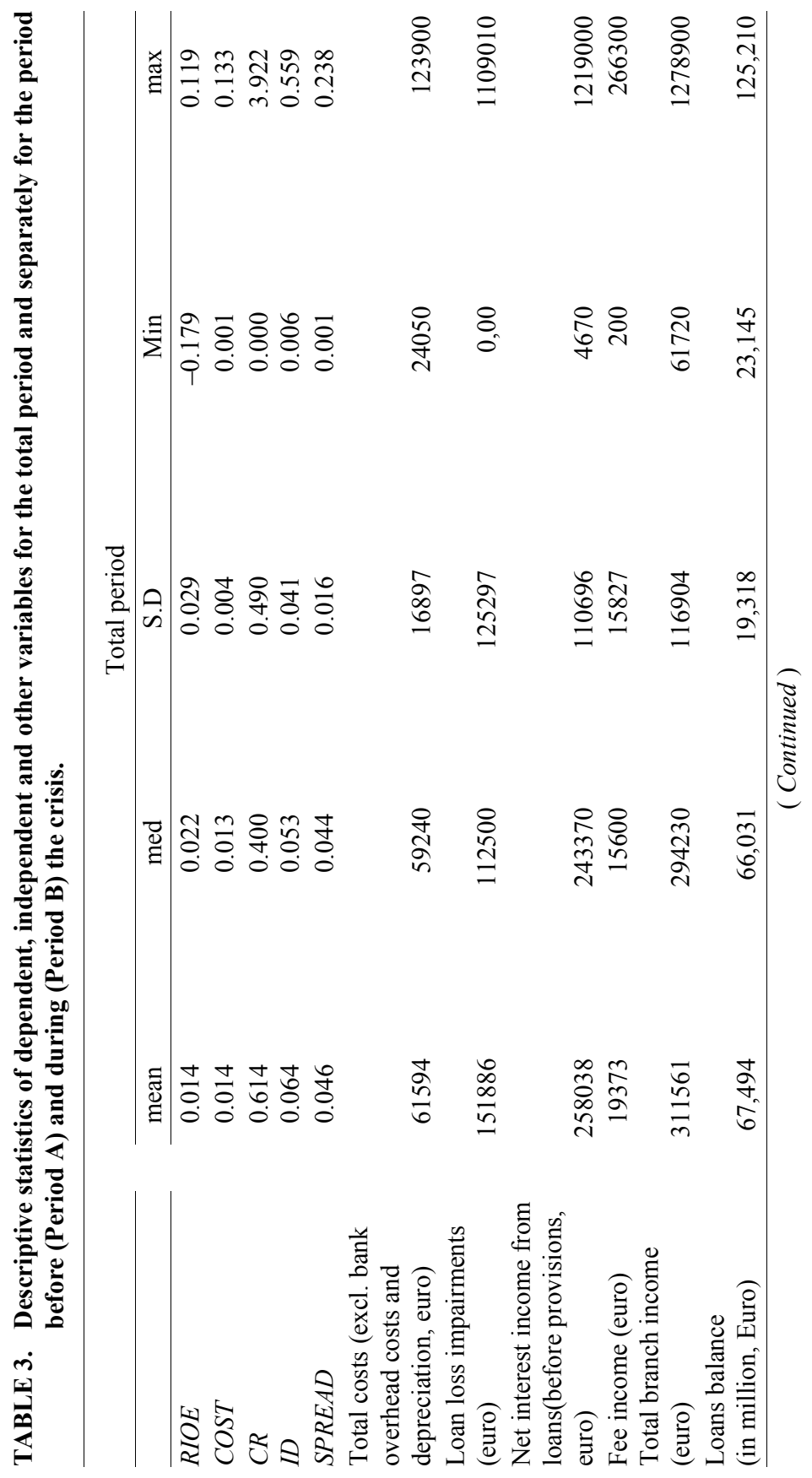




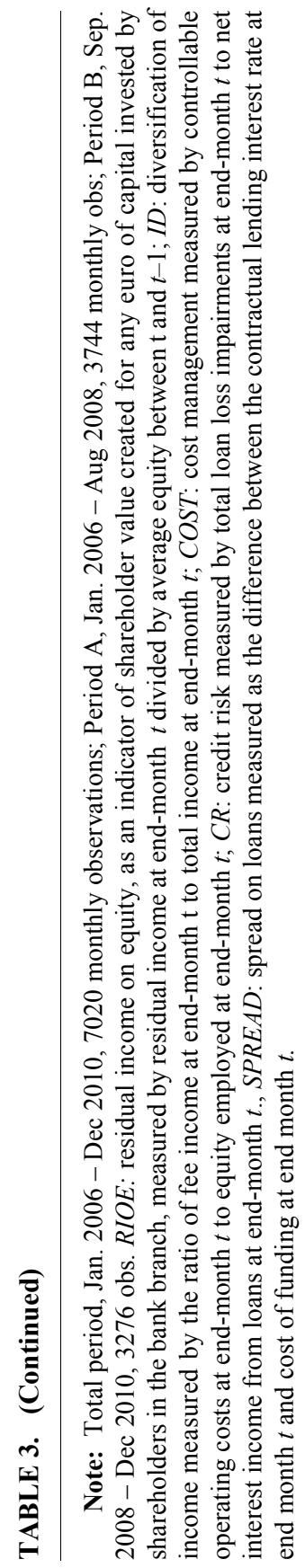


TABLE 4. Pearson correlation coefficients of variables used in the shareholder value driver analysis

\begin{tabular}{llclll}
\hline Variables & RIOE & $D$ & $C R$ & $C$ & $S$ \\
\hline RIOE & 1 & & & & \\
$I D$ & -0.0010 & & & & \\
& $(-0.08)$ & 1 & & & \\
$C R$ & -0.8887 & -0.0034 & & & \\
& $(-1.62)^{* * *}$ & $(-0.29)$ & 1 & & \\
COST & 0.0613 & 0.1052 & -0.1302 & & \\
& $(5.14)^{* * *}$ & $(8.86)^{* * *}$ & $(-1.10)^{* * *}$ & 1 & \\
SPREAD & 0.4229 & -0.3461 & -0.2628 & 0.0106 & \\
& $(3.91)^{* * *}$ & $(-3.09)^{* * *}$ & $(-2.21)^{* * *}$ & $(0.88)$ & 1 \\
\hline
\end{tabular}

Note: The variables are as follows: RIOE: residual income on equity; ID: diversification of income measured by the ratio of fee income at end-month $t$ to total income at end-month $t$; COST: cost management measured by controllable operating costs at end-month $t$ to equity employed at end-month $t$; $C R$ : credit risk measured by total loan loss impairments at end-month $t$ to net interest income from loans at end-month $t$., SPREAD: Spread on loans measured as the difference between the contractual lending interest rate at end month $t$ and cost of funding at end month $t$. Also, ${ }^{* * *}, * *$, and * represent statistical significance of the coefficients at $1 \%, 5 \%$ and $10 \%$ levels, respectively.

The descriptive statistics of the estimated dependent, independent and other variables for the homogenous sample of 117 branches, focusing initially in the total period of the analysis and separately before the financial crisis (Period A: January 2006-August 2008) and during the crisis (Period B: September 2008-December 2010), are presented in table 3. In summary, significant differences in SHV creation for our sample retail branches are observed when comparing the two periods.

Finally, as shown in table 4 the magnitude of the estimated correlation coefficients between the independent variables is usually smaller than $15 \%$ (except in two cases where the coefficients are around $34 \%$ and $26 \%$ ), suggesting that the model do not suffer from multicollinearity problems.

\section{Methology}

\section{A. Model Specification}

The SHV creation in retail branches, measured by $R I$ (dependent variable), is linked to four potential value drivers (independent variables). In order to control for size effects and minimize heteroscedasticity in the model, the $R I$ is standardized by Equity (RIOE) 
so that this ratio expresses the shareholder value created for any euro of capital invested by shareholders in the bank branch. As independent variables are incorporated into the model the income diversification (ID), the cost management (COST), the credit risk $(C R)$ and the lending spreads $(S P R E A D)$. For capturing the effect of value drivers on $R I$, given that the crisis occurred, a crisis dummy variable (CD) is introduced taking on the value of 1 in the period of the financial crisis and 0 otherwise (Iqbal and Kumel, 2014). This dummy variable is multiplied separately with each of the four independent variables and thus four interaction variables included in the model, the coefficients of which show the supplementary impact of each independent variable on the $R I$ in periods of credit crunch. It is worth noting that are not incorporated into the model macro or regional economic determinants as control variables, such as the disposable income per capita or the unemployment rate, since these variables were found to be fixed over monthly periods.

A fixed-effects panel data regression model is specified to account for the individuality of each branch as well as time effects. The fixed-effects model specification is illustrated assuming constant slope coefficients but intercepts that vary over time or individual branches (Baltagi, 2005). Because extremes in the values of the dependent and independent variables might distort the true picture of the relationship between these variables, before running the regression the dependent and independent variables are winsorized at 5\% in both tails (the lower and upper five percent of the observations of the variables are replaced with the next value inwards from these extreme tails):

$$
\begin{aligned}
\operatorname{RIOE}_{i t}= & \alpha+\mu_{i}+\lambda_{t}+b_{1} I D_{i t}+b_{2} \operatorname{COST}_{i t}+b_{3} C R_{i t}+b_{4} \operatorname{SPREAD}_{i t}+ \\
& b_{5} C D * I D_{i t}+b_{6} C D * \operatorname{COST}_{i t}+b_{7} C D * C R_{i t}+ \\
& b_{8} C D * S P R E A D_{i t}+u_{i t}
\end{aligned}
$$

The definition of each independent variable is given above on table 1 . Also: $i$ denotes the number of retail branches ( 1 to 117 for the homogeneous sample of branches); $t$ denotes the corresponding months (1 to 60); $C D$ is the crisis dummy indicator variable as described above and $u_{i t}$ denotes the disturbance term which varies with branches and time. The differences across branches are captured in differences in the constant term $\mu_{i}$ and differences over time in the constant term of $\lambda_{t}$. The branch specific effects and period specific effects are assumed fixed parameters to be estimated as coefficients of branch dummies and period dummies for each retail branch and for each period in the sample respectively. The estimations of the above fixed-effects specification are 
corrected for heteroscedasticity by using the White (diagonal) robust coefficient variance method (Arellano, 1987; White, 1980).

\section{B. Fit of model specification}

In order to test the fit of the above fixed-effects model to the data set, several tests are performed (the results are presented below at table 5 Panel B). Initially the stationarity of the panel is tested since the use of relatively large periods $T$ as in our study $(T=60)$ may indicate non-stationarity of the panel. The Fisher unit-root test is employed for the identification of stationarity in variables. The null hypothesis of non-stationarity is rejected at the $1 \%$ level for the dependent and independent variables.

Then a basic F-test is run for joint parameter insignificance. With an F-statistic of 2752.21 (with 4 and 6,836 degrees of freedom), the null hypothesis that coefficients are jointly insignificant at the $1 \%$ level is rejected and thus does not show a misspecification of the model. The next step is to test that branch specific effects exist and that the fixed-effects model is preferred over the pooled regression model which assumes omission of the bank and time variant effects. With an Fstatistic of 15.95 (with 116 and 6,836 degrees of freedom), the null hypothesis that coefficients of branch dummies are redundant and equal to zero at the $1 \%$ level is rejected. Also, the null hypothesis (F-statistic of 122.94 with 59 and 6,836 degrees of freedom) that all the coefficients of time-dummies are jointly equal to zero is rejected as well as all the coefficients of branch dummies and time dummies are jointly equal to zero (F-statistic of 54.98 with 175 and 6836 degrees of freedom). Results therefore suggest that individual branch specific effects and time period effects exist and the appropriate model is the fixed-effects model.

The final test is to examine that the effects are fixed and not random. The nature of the data indicates that the branch-specific effects are correlated with the independent variables (for example some branch managers with an experience-managerial skills effect-have the discretion to charge lower spreads on loans). The Hausman test statistic (Hausman, 1978) with a value of 138.88 rejects the null hypothesis that independent variables are not correlated with the branch specific effect. In summary, the results of the above tests conducted suggest that the fixed-effects model produces efficient coefficient estimates.

\section{Alternative models}

In order to further confirm the fit of the fixed-effects model to the data 
set, different robustness checks are run. As Garcia-Herrero, Gavila and Santabarbara (2009) outline, when estimating bank performance the researcher faces three challenges: One is the risk of omitted variables, the second is endogeneity and the last is the potential persistence of the dependent variable.

As regards the first challenge, the use of fixed-effects at the branch and month level effectively reduces the omitted variable bias. With respect to endogeneity problems the results are expected to not suffer from it, since the study explores crisis effects on the SHV determinants in the retail banking where there is an exogenous shock to the banking industry. To econometrically confirm this, a Two-Stage Least Squares panel model (TSLS) is applied, often employed in the context of endogeneity (Wooldridge, 2009). The first lag of all independent variables which could potentially suffer from endogeneity, is used as instrumental variables. The last challenge is the persistence of the dependent variable RIOE. The economic rationale is that bank net operating income shows a tendency to persist over time and there is also a need to account for the autoregressive process in the data regarding the behavior of $R I$. Therefore a dynamic specification of the model is adopted by including a lagged dependant variable (first lag of $R I O E$ ) among the independent variables as various studies applied (Fiordelisi and Molyneux, 2010; Athanasoglou, Brissimis and Delis, 2008). The system Generalized Method of Moments (GMM) estimators, developed for dynamic panels by Arellano and Bond (1991), is used to assess the relationship between SHV and its determinants. Also, this methodology accounts for endogeneity, so the lagged values (first lag) of all the independent variables are used as instruments. Arrelano and Bond (1991) proposed the one and two-step estimators. The one-step GMM estimator ${ }^{9}$ is employed, corrected for serial correlation and time varying variances in the disturbances by using the White period robust coefficient variance method.

\section{Empiricial findings}

This section describes the econometric results for the homogenous

9. Monte Carlo studies have found that this estimator outperforms the two-step estimator both in terms of producing a smaller bias and a smaller standard deviation of the estimates (Judson and Owen, 1999). Also, the panel data of this study is characterized by a large $\mathrm{T}(\mathrm{T}=60)$, coping with the argument that Arrellano and Bond estimators are inefficient when applied to panel with very small $\mathrm{T}$. 
TABLE 5. Panel data regression results for different models and the redundant fixed-effects tests.

\begin{tabular}{lccc} 
A. regression results & & & \\
RIOE Ratio & FE model & TSLS model & GMM model \\
\hline Intercept & $0.0311^{* * *}$ & $0.0244^{* * *}$ & - \\
$R I O E_{t-1}$ & - & - & -0.0013 \\
$I D$ & $0.0518^{* * *}$ & $0.0624^{* * *}$ & $0.0538^{* * *}$ \\
$C O S T$ & $-0.7486^{* * *}$ & $-0.2785^{* * *}$ & $-1.8390^{* * *}$ \\
$C R$ & $-0.0417^{* * *}$ & $-0.0444^{* * *}$ & $-0.0642^{* * *}$ \\
$S P R E A D$ & $0.7178^{* * *}$ & $0.8364^{* * *}$ & $0.7659^{* * *}$ \\
$C D^{*} I D$ & $-0.0935^{* * *}$ & $-0.1151^{* * *}$ & $-0.1630^{* * *}$ \\
$C D^{*} C O S T$ & $-0.4772^{* * *}$ & $-0.6111^{* * *}$ & $-1.6590^{* * *}$ \\
$C D^{*} C R$ & $-0.0089^{* * *}$ & $-0.0078^{* * *}$ & $0.0168^{* * *}$ \\
$C D^{*} S P R E A D$ & $-0.4234^{* * *}$ & $-0.5745^{* * *}$ & $-0.8125^{* * *}$ \\
$R^{2}$ & 0.9663 & 0.9643 & - \\
$\mathrm{J}-$-statistic & - & - & 5,913 \\
\hline
\end{tabular}

B. redundant FE model tests

\begin{tabular}{|c|c|c|c|c|c|}
\hline \multicolumn{3}{|l|}{ Effects test } & \multicolumn{2}{|l|}{ Statistic } & Probability \\
\hline \multicolumn{3}{|c|}{ Joint coefficient insignificance $\mathrm{F}$} & 2752.21 & & 0.000 \\
\hline \multicolumn{3}{|c|}{ Cross - section F } & 15.95 & & 0.000 \\
\hline \multicolumn{3}{|c|}{ Period F } & 122.94 & & 0.000 \\
\hline \multicolumn{3}{|c|}{ Cross- section/period F } & 54.98 & & 0.000 \\
\hline \multicolumn{6}{|c|}{ Fisher panel unit root for dependent and independent variables } \\
\hline Variables & RIOE & $I D$ & COST & $C R$ & SPREAD \\
\hline Test statistic & 319.38 & 602.25 & 1439.20 & 765.23 & 1088.74 \\
\hline Probability & 0.000 & 0.000 & 0.000 & 0.000 & 0.000 \\
\hline
\end{tabular}

Note: This table reports the panel data regressions results (Panel A) using equation (2) for the Fixed-Effects (FE) model specification, the Two-Stage Least Squares (TSLS) model specification and the Generalized Method of Moments (GMM) model specification respectively and also the redundant fixed-effects tests (Panel B). The variables are as follows: RIOE: residual income on equity, as an indicator of shareholder value created for any euro of capital invested by shareholders in the bank branch, measured by residual income at end-month $t$ divided by average equity between $t$ and $t-1 ; I D$ : diversification of income measured by the ratio of fee income at end-month $t$ to total income at end-month $t$; COST: cost management measured by controllable operating costs at end-month t to equity employed at end-month $t$; $C R$ : credit risk measured by total loan loss impairments at end-month $t$ to net interest income from loans at end-month $t$. SPREAD: Spread on loans measured as the difference between the contractual lending interest rate at end month $t$ and cost of funding at end month $t$; $C D$ : a crisis dummy variable taking on the value of 1 in the period of the financial crisis and 0 otherwise; $C D^{*} I D, C D^{*} C O S T, C D^{*} C R, C D^{*} S P R E A D$ : the coefficients of these variables measure the supplementary impact of each independent variable on the $R I O E$ given the crisis occurred. For the fixed-effects specification the estimates are corrected for heteroscedasticity by using the White (diagonal) robust coefficient variance method. 
TABLE 5. (Continued)

\begin{abstract}
Note: The reported R-squared (estimated by e-views which is based on the difference between the residual sums of squares form the estimated model and the sums of squares from a single constant only specification, not from a fixed-effects only specification) describes the explanatory power of the entire specification including the estimated fixed-effects. For the TSLS model specification, we use lagged values (first lag) of all the independent variables as instruments which could potentially suffer from endogeneity. Finally, for the GMM model specification, we include a lagged dependant variable (first lag of $R I O E$ ) among the independent variables to account for persistence. Also, we use lagged values (first lag) of all the independent variables as instruments, which could potentially suffer from endogeneity. We employ the one-step GMM estimator (corrected for serial correlation and time varying variances in the disturbances by using the White period robust coefficient variance method). Also, $* * *, * *$, and $*$ represent statistical significance of the coefficients at $1 \%, 5 \%$ and $10 \%$ levels, respectively. Finally: number of cross-sections used 117; number of time- periods 60 ; total panel balanced observations 7,020. (See equation 2)
\end{abstract}

sample branches and the three branch network samples respectively.

\title{
A. Econometric results for the homogeneous sample branches
}

In table 5 the efficient coefficient estimates of the fixed-effects model, the TSLS model, the one-step GMM specification (Panel A) and the redundant fixed-effects tests (Panel B) are presented. As regards the one-step GMM specification, the lagged dependent variable, which measures the degree of persistence of the dependent variable RIOE, is not statistically significant, so the use of a dynamic model is not justified. Also, the efficient coefficient estimates of the TSLS model are very similar to the estimates of fixed-effects model specification.

Looking at the impact of diversification of income on SHV, it is observed that the specific diversification creates value as shown by the positive and statistically significant coefficient $(+0.0518)$ at the $1 \%$ level. This finding therefore strongly suggests that branches with a high share of fee income relative to total income create more value. This result stands in line with the results of Cipollini and Fiordelisi (2012) and Fiordelisi and Molyneux (2010). However this positive relationship between SHV and income diversification doesn't hold anymore during crisis years. The crisis causes a reduction of the value of the coefficient by -0.0935 (statistically significant at the $1 \%$ ), bringing the total effect to a negative coefficient $-0.0417(0.0518-0.00935)$. This negative impact of diversification on SHV indicates that a diversified business mix is not appropriate during the crisis (taking into account also the decreased fee operation volumes that are recorded that period) and the bank management should focus on the efficient allocation of the resources to operations that are related with the remedial management 
of loan portfolio. This result verifies the research hypothesis (H1) and stands in contrast to the findings of Dietrich and Wanzenried (2010), who point out a positive relationship between income diversification and bank profitability for the Swiss banking sector during the crisis period. This different finding is attributed to the different structure of both the Greek and the Swiss commercial banking that leads to a differentiated approach of fee income in the two industries. This implies a different research design and findings. Specifically, this study examines pure retail banking operations of branch networks where fee income is related to network commissions. In turn, Dietrich and Wanzenried (2010) explore different types of commercial banking operations (cantonal banks, regional and saving banks, Raiffeisen banks, other banks specializing in the stock exchange, securities and asset management) where the non interest income includes also and trading operations. So they conclude a positive profitability effect of income diversification reflected in a positive development of the stock market and a higher stock exchange turnover.

Furthermore, the study reveals that inefficient cost management destroys value as shown by the negative and statistically significant coefficient $(-0.7486)$ at the $1 \%$ level. The more efficient a branch is the higher is its SHV creation. This result supports the findings of the existing SHV literature (Fiordelisi and Molyneux, 2010; Gross, 2006). Accordingly, the "cost skimping" hypothesis - as branches become more cost efficient they also this increases their non-performing loansis not supported by the study findings. The crisis destroys value more, increasing the value of the coefficient by -0.4772 (statistically significant at the $1 \%)$, bringing the total effect to $-1.2259((-0.7486+$ $(-0.4772))$. This result supports the research hypothesis (H2) and is relevant to the finding of Dietrich and Wanzenried (2010) who suggest that an increase in cost efficiency during the crisis can offset the decrease in profits due to falling demand for new loans and thus create value.

Regarding the impact of credit risk taking on value creation, it is observed that higher credit risk destroys value as shown by the negative and statistically significant coefficient $(-0.0417)$ at the $1 \%$ level. This finding therefore strongly suggests that branches with higher risk capabilities create more value than other branches. This result stands in line with the results of Fiordelisi and Molyneux (2010) and Gross (2006). Accordingly, the "good luck" hypothesis - as branches take on more credit risks they also boost their interest revenues - is not supported by the results. The crisis period destroys value more, increasing the value of that specific coefficient by -0.0089 (statistically significant at the $1 \%)$, bringing the total effect to $-0.0506((-0.0417+$ $(-0.0089))$. The reason for this extra negative impact on SHV is that 
TABLE 6. Summary of the results (impact on value determinants on RI, taking into account the financial crisis)

\begin{tabular}{|c|c|c|c|c|c|c|}
\hline \multirow[b]{2}{*}{ Policy field } & \multirow{2}{*}{\multicolumn{2}{|c|}{$\begin{array}{c}\text { Total Period } \\
\text { sign } \quad \text { St.sign }(1) \\
\end{array}$}} & \multirow{2}{*}{\multicolumn{2}{|c|}{$\begin{array}{l}\text { Crisis Period } \\
\text { sign } \quad \text { St.sign }(1)\end{array}$}} & \multicolumn{2}{|c|}{$\begin{array}{l}\text { Incremental impact of each } \\
\text { factor in the crisis period ( } 2 \text { ) }\end{array}$} \\
\hline & & & & & $\begin{array}{l}\text { Non } \\
\text { Statistical } \\
\text { significant }\end{array}$ & $\begin{array}{l}\text { Statistical } \\
\text { significant }\end{array}$ \\
\hline $\begin{array}{l}\text { Income } \\
\text { diversification }\end{array}$ & + & $* * *$ & - & $* * *$ & & $\downarrow * * *$ \\
\hline $\begin{array}{l}\text { Cost } \\
\text { management }\end{array}$ & - & $* * *$ & - & $* * *$ & & $\uparrow * * *$ \\
\hline Credit risk taking & - & $* * *$ & - & $* * *$ & & $\uparrow * * *$ \\
\hline Lending spreads & + & $* * *$ & - & $* * *$ & & $\downarrow * * *$ \\
\hline
\end{tabular}

Note: (1) Statistical Significance Index: *** at 1\%, **at 5\%, * at 10\%. (2) Denotes the incremental impact (increase or decrease) of each value determinant on $R I$-given that the crisis occurs- along with its statistically significance.

loan loss impairments have significantly increased during the crisis. This result verifies the relevant research hypothesis $(\mathrm{H} 3)$ and stands in line with the findings of Dietrich and Wanzenried (2010), who report a negative impact of credit risk taking on profitability during crisis years.

Finally, an increase on lending spreads creates SHV as shown by the positive and statistically significant coefficient $(+0.7178)$ at the $1 \%$ level. This finding suggests that branches which charge higher lending margins to their loan customers create more value than other branches. Also, the effect of higher interest income seems to over compensate the risk that high interest margins may lead to a decrease in credit quality. This result is in line with the results of Dermine (2010, 2009). However, things look different for the crisis years, which is quite interesting. The financial crisis reduces the value of that coefficient by -0.4234 (statistically significant at the 1\%), bringing the total effect to +0.2944 $(0.7178-0.4234)$. This result supports the research hypothesis $(\mathrm{H} 4)$ and provides empirical evidence of the increased risk that entered into branch loan portfolio during the expansion period and revealed in the crisis years.

Table 6 summarizes the above relationships.

\section{B. Econometric results for the total branch network samples}

As mentioned above, the strict homogeneity criterion is relaxed and the model is run for three branch network samples given the branch size, the branch location and the ability of each branch to use its own deposits to 


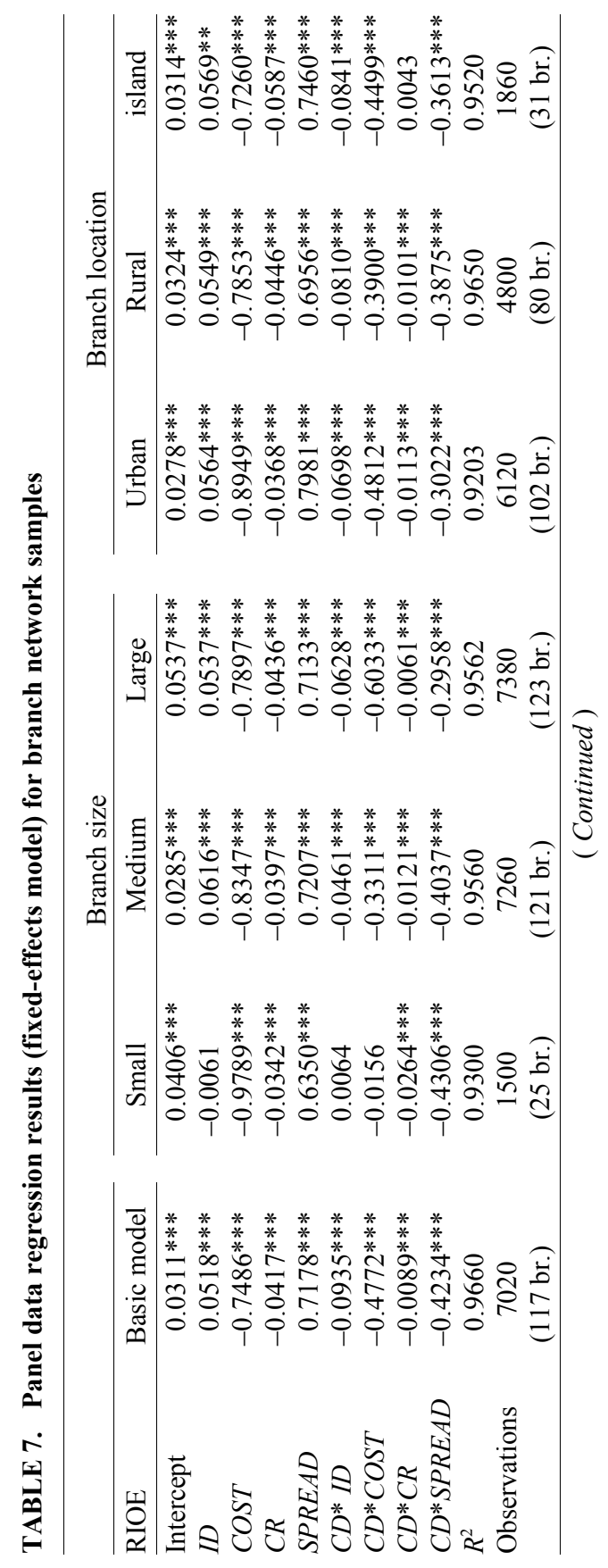




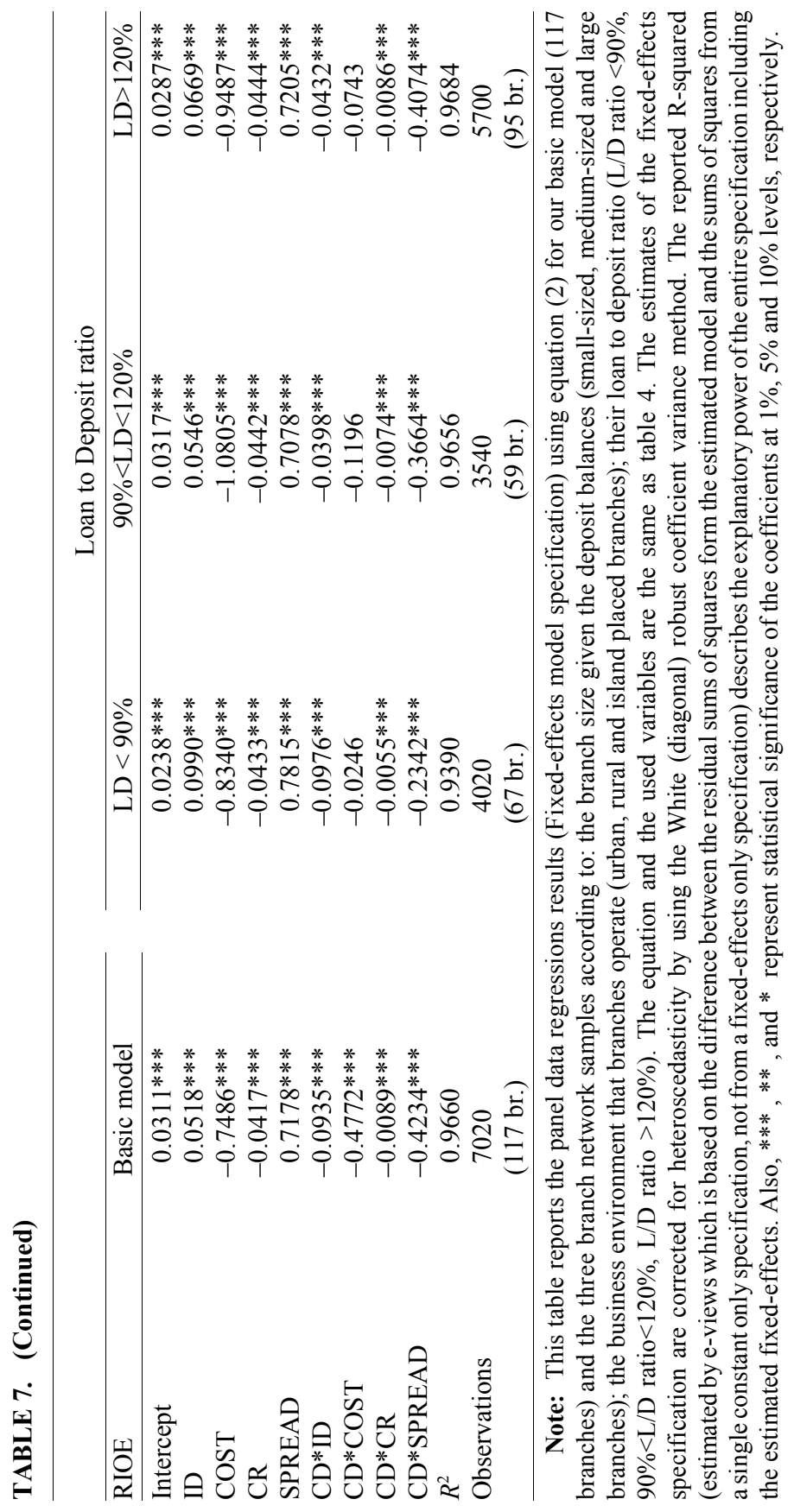


make loans.

In table 7 the efficient coefficient estimates of the fixed-effects model are presented, for both the basic model (results of table 5 for the 117 branches) and the three branch network samples models. As regards the branch size criterion, the results of the basic model are confirmed in sign and significance in the medium-sized and large-sized branches samples. Some different results are found when we look at the small-sized branches sample, where the income diversification variable has a negative sign but with no statistical significance $(-0.0061)$. During the crisis the value of that coefficient is positive $(+0.0064)$, but with no statistical significance. So, the competitive advantage of a diversified business mix doesn't seem to be significant for the small-sized branches. Also, for the variable of operating expenses management the negative sign during the crisis $(-0.0156)$ is confirmed but with no statistical significance. As regarding the business environment that branches are operating, the results for the branches operating in urban and rural areas respectively are the same and confirm those of the basic model. Some different results are found in the sample composed of branches operating on islands, for which the credit risk variable has a positive sign during the crisis $(+0.0043)$, but with no statistical significance. Finally as regarding the criterion of loan to deposits ratio, the results of the basic model are confirmed in sign and significance for all three samples. Some variations are found for the variable of cost management - for all models- during the crisis, where although the sign is negative such as the basic model, there is no statistical significance.

Thus, the results do not depend on the different size of branches, except for small-sized branches as regarding the impact of income diversification; results do not change based on the location of branches, except for branches operating on islands as regarding the impact of credit risk in the crisis period; results do not change based on the ability of a branch to finance loans by its own deposits.

\section{Discussion and conclusions}

This section summarizes our main findings and presents some policy implications.

\section{A. Main findings}

This paper examines the recent crisis effects on branch bank 
performance in terms of SHV of one of the four largest Greek commercial banks over the period 2006-2010. This unique data set of unpublished monthly P\&L statements of retail branches is ideally suited to investigate the SHV process as Greece, being part of the Euro zone crisis, offers a unique environment (sovereign debt) to analyze factors of value creation and destruction. A fixed-effects model specification is used which produces efficient estimates according to the different estimation methods that the study employed. This study finds that diversification, cost management, credit risk, and lending spreads are all significantly associated with the $R I$, but with a different statistical sign. In particular, the findings reveal that diversified income, efficient cost management and high lending spreads in general, all increase SHV significantly. Taking into account the branch network samples, the income diversification variable doesn't seem to be significant for small-sized branches. In contrast, high credit risk expressed in accumulated loan impairments destroys value substantially. SHV literature supports the findings as regards diversified income (Cipollini and Fiordelisi, 2012; Fiordelisi and Molyneux, 2010), credit risk (Gross, 2006) and cost management (Fiordelisi and Molyneux, 2010; Gross, 2006). The result for the impact of income diversification is somewhat different from the findings of Dietrich and Wanzenried (2010) due to differences in the commercial banking structure of Greece and Switzerland. Also, the findings for credit risk and cost management are in line with the results of Athanasoglou, Brissimis and Delis (2008) who investigated profitability determinants for the Greek banking sector.

In the period of the financial crisis, important and statistically significant changes in the SHV effect of the independent variables are observed. In particular, income diversification and lending spreads lose their dynamic causing a statistically significant reduction in SHV. For income diversification the impact of the crisis is substantial in reversing the value effect from a value premium to value destruction. At the same time, cost management increases its positive value effect with a statistical significance. Moreover, (in the crisis period) the enormous increase of loan loss impairments relative to the income of loans (credit risk) exercises an extra negative impact on SHV thus further accelerating shareholder value destruction, excluding the branches operating on islands due to positive effects of international tourism. This finding provides evidence for loan portfolio segmentation across several geographical areas in order to implement different resolution processes. 
To sum up, this study sheds light on the issue of retail banking performance exhibiting the specific challenges for the bank management in contrasting periods. Thus, it refreshes the conventional bank performance discussion through the analysis of SHV creation and destruction at bottom bank level. Furthermore, it enriches the specific discussion through the investigation of the impact of an exogenous shock in terms of crisis effects to the banking industry.

\section{B. Policy implications}

The study findings have some important management implications: Firstly, in the crisis period, it appears that the strategic priority for the bank management should be the reorganization of loan portfolios given the negative value impact of credit risk and the reduction of value premium of lending spreads. In this case, a revised credit policy of covering unsecured loans with collateral and lowering simultaneously the loan rate as an incentive to borrowers to provide collateral, might help to increase SHV. This would be achieved by recording interest income in the case of NPL and lowering the provision coefficient rates of secured loans. Also, the destructive value effect of lending spreads during the crisis indicates that the adoption of a repricing policy to the loan's portfolio is not appropriate and seems to reduce the repayment ability of lenders. Secondly, our findings indicate the requirement for a pro-active credit policy in the growth period and they provide a rationale for countercyclical loan loss impairments. Consequently, banks should make provisions during good times for the increased risk that enters into their portfolios. Thirdly, the crisis stresses the importance of concentration of banking activity on core business and mainly on remedial and NPL management, instead of fee-based banking products. Remedial management can be implemented by providing restructuring solutions to lenders and improving the collection performance and the collaterals of loan accounts, while NPL management should focus on NPL recoveries through enhancing non performing customer's general divisions and units. Finally, an efficient branch management of operational expenses encouraged by the intensification of branch rationalization measures (premises rationalization, salary freezes, staff retrenchments etc.), streamlining of administration functions and processes and the application of new technologies (e.g., internal electronic systems) might help to create SHV in the crisis years. It is worth noting that efficiency gain actions such as 
retail network rationalization, voluntary exit schemes and centralization of supporting functions were incorporated to strategic transformation programs of all the Greek systemic banks during crisis years.

Overall, the empirical findings can have important implications for the Greek economy itself given the crucial role of Greek banks to finance the real economy. More specifically, the location of significant sources of value creation and destruction at the bottom-level of banking institutions provide important implications for the assessment of the quality of bank performance and the change of its dynamic in the turbulent crisis environment, for both the bank managers and the policymakers. In addition, the empirical results offer useful lessons to other EU peripheral crisis economies such as Italy, Spain, and Portugal with similar banking operations (e.g. pure retail banking) revealing the important role of crisis in the total value creation process.

This study has practical relevance due to the following reasons: The paper indicates an acceleration of SHV destruction caused by credit risk in the crisis years. This finding stresses the importance of setting rules to manage credit risk, hence supporting the post-crisis initiatives taken by policymakers in the EU (European Banking Authority -EBA-, $2014)^{10}$ for the effective management of NPL and arrears, attempting to achieve a single evaluation approach of credit portfolios by European banks. In addition, the results support specific SHV enhancing credit policies related with collateral management, repricing of existing loans and loan portfolio segmentation which might enrich EBA technical standards. Also, this study suggests a proactive and countercyclical policy for the avoidance of SHV destruction of credit risk. This provides further support to banking regulation ${ }^{11}$ in terms of capital requirements necessary to absorb losses related to credit risk. The findings have practical implications for bank management. In the crisis years bank management should exhibit much more flexibility in restructuring loan portfolios through the establishment of an independent, organizational, division of managing arrears and NPL at institution level, and the

10. EBA published on 20/2/2014 a final draft: Implementing of technical standards on Supervisory reporting on forbearance and non performing exposures under article 99(4) of Regulation (EU) No 575/2013. These technical standards were incorporated into Bank's of Greece supervisory practices through the Bank of Greece Executive Committee's Act No 42/30.05.2014.

11. EBA published on 23/12/2014 a final draft: Regulatory technical standards on disclosure of information in relation to the compliance of institutions with the requirement for a countercyclical capital buffer under Article 440 of Regulation (EU) No 575/2013. 
concentration of branch networks solely on credit provision.

The analysis was based on the fact that the banking crisis in Greece originated primarily from the sovereign debt crisis in the country and that domestic institutions were not the primary cause of the crisis. Therefore, special policy measures and regulatory advancements are needed to weaken the links between sovereigns and banks and thus reduce exogenous shocks to the banking industry. The recent announcement by the ECB to buy substantial amounts of government bonds each month from across the Euro zone, is expected to infuse valuable liquidity in the banking system with important positive implications for credit provision and risk as well as banking performance and stability in general.

Further investigation is required with alternative SHV models in different crisis countries and an extended set of value drivers which can cross validate the present research, thus enriching relevant discussion.

Accepted by: P.C. Andreou, PhD, Editor-in-Chief(Pro-Tem), March 2015

\section{References}

Andreou, P.; Philip, D.; and Robejsek, P. 2013. Shareholder value efficiency: Methods and evidence from the US banking industry. Available at SSRN: http://ssrn.com/abstract=2489014.

Arellano, M. 1987. Computing robust standard errors for within-groups estimators. Oxford Bulletin of Economics and Statistics, Department of Economics, University of Oxford 49: 431-434.

Arellano, M., and Bond, S. 1991. Some tests of specification for panel data: Monte Carlo Evidence and an Application to Employment Equations. Review of Economic Studies 58: 277-297.

Athanasoglou, P.; Brissimis, S.; and Delis, M. 2008. Bank specific, industry specific and macroeconomic determinants of bank profitability. Journal of International Financial Markets, Institutions and Money, 18:121-136.

Baltagi, B. 2005. Econometric Analysis of Panel Data. New York: John Wiley\&Sons.

Bank of Greece, 2014. The time of the great depression: The Bank of Greece 2008-2013, Bank of Greece, Athens.

Bank of Greece, December 2009. Financial Stability Report, Bank of Greece, Athens. Available at: http://www. bankofgreece. gr/Bog Ekdoseis/ fstability 200912_en.pdf.

Bank of Greece, July 2010, Financial Stability Report, Bank of Greece, Athens. Available at: http://www. bankofgreece. gr/BogEkdoseis/fstability201007 _en.pdf. 
Bank of Greece, Governor's Acts No 2588, 2589, 2590, 20.08.2007. Bank of Greece, Athens

Bank of Greece, Executive Committee's Act No 42/30.05.2014. Bank of Greece, Athens.

Beccalli, E.; Casu, B.; and Girardone, C. 2006. Efficiency and stock performance in European banking. Journal of Business Finance and Accounting, 33: 218-235.

Berger, A., and Mester, L. 2003. Explaining the dramatic changes in performance of US banks: technological change, deregulation and dynamic changes in competition. Journal of Financial Intermediation 12: 57-95.

Berger, A., and De Young, R. 1997. Problem loans and cost efficiency in commercial banking, Journal of Banking and Finance 21: 849-870.

Brissimis, S.; Delis, M.; and Papanikolaou, N. 2008. Exploring the nexus between banking sector reform and performance: Evidence from newly acceded EU countries. Journal of Banking and Finance 32: 2674- 2683.

Cipollini A., and Fiordelisi F. 2012. Economic value, competition and financial distress in the European banking system, Journal of Banking and Finance 36: 3101-3109.

Damodaran, A. 2012. Equity Risk Premiums (ERP): Determinants, Estimation and Implications - The 2012 Edition. Available at SSRN: http ://ssrn .com /abstract $=2027211$.

Damodaran, A. 2010. Into the Abyss: What If Nothing is Risk Free? Available at SSRN: http://ssrn.com/abstract=1648164.

Damodaran, A. 2009. Valuing Financial Service Firms. Working paper. Stern Business School: New York University. Available at: http:// people. stern . nyu. edu/adamodar/pdfiles/papers/finfirm09.pdf

Demirguk-Kunt, A.; Detragiache, E.; and Gupta, P. 2006. Inside the Crises: An empirical Analysis of Banking Systems in Distress. Journal of International Money and Finance 25: 702-718.

Demirguk-Kunt, A., and Huizinga, H. 1999. Determinants of commercial bank interest margins and profitability: Some international evidence. World Bank Policy Research Working Papers. Available at: http:// elibrary .worldbank .org/doi/book/10.1596/1813-9450-1900.

Dermine, J. 2010. Bank valuation with an application to the implicit duration of non-maturing deposits. International Journal of Banking, Accounting and Finance 2: 1-30.

Dermine, J. 2009. Bank Valuation and Value - Based Management. New York: McGraw - Hill

Deville, A. 2009. Branch banking network assessment using DEA: A benchmarking analysis - A note. Management Accounting Research 20: 252-261.

Dietrich, A., and Wanzenried, G. 2011. Determinants of bank profitability before and during the crisis: Evidence from Switzerland, Journal of International Financial Markets, Institutions and Money 21: 307-327. 
European Banking Authority -EBA-, February 2014. A final draft: Implementing of technical standards on Supervisory reporting on forbearance and non performing exposures under article 99(4) of Regulation (EU) No 575/2013.Availabe at: https :// www. eba. europa. eu/documents /10180/449824/EBA-ITS-2013-03+Final+draft+ITS+on+Forbearance+a nd+Non-performing+exposures.pdf

European Banking Authority-EBA-, December 2014. A final draft; Regulatory technical standards on disclosure of information in relation to the compliance of institutions with the requirement for a countercyclical capital buffer under Article 440 of Regulation (EU) No 575/2013. Available at: https://www.eba.europa.eu/documents/10180/937795/EBA+RTS+2014+ 17+\%28Final+Draft+RTS+on+CCB+Disclosure\%29.pdf

Eichengreen, B., and Gibson, H. 2001. Greek banking at the dawn of the new millennium. CERP Discussion paper No 2791. Available at SSRN: http://ssrn.com/abstract=269391.

Feltham, G., and Ohlson, J. 1995. Valuation and Clean Surplus Accounting for Operating and Financial Activities. Contemporary Accounting Research 11: 689-731.

Fernandez, P.; Aguirreamalloa, J.; and Avendapo, L. 2011 Market Risk Premium Used in 56 Countries in 2011: A Survey with 6,014 Answers. Available at SSRN: http://ssrn.com/abstract=1822182.

Fiordelisi, F.; Marquez - Ibanez, D.; and Molyneux, P. 2011. Efficiency and risk-taking in European banking. Journal of Banking and Finance 35: 1315-1326.

Fiordelisi, F., and Molyneux P. 2010. The determinants of shareholder value in European banking. Journal of Banking and Finance 35: 1189-1200.

Fiordelisi, F. 2007. Shareholder value efficiency in European banking. Journal of Banking and Finance 31: 2151-2171.

Fiordelisi, F., and Molyneux, P. 2007. Value Creation in Banking. EFA 2007 Ljubljana Meetings paper. Available at SSRN: http: //ssrn .com /abstract $=965441$.

Garcia-Herrero, A.; Gavila, S.; and Santabarbara, D. 2009. What explains the low profitability of Chinese banks? Journal of Banking and Finance 33: 2080-2092.

Garvey, G., and Milbourn, T. 2000. EVA versus Earnings: does it matter which is more highly correlated with stock returns? Journal of Accounting Research 38: 209-245.

Goddard, J.; Molyneux, P.; and Wilson, J. 2004. The profitability of European Banks: a cross sectional and dynamic panel analysis, Manchester School 72: 363-381.

Gross, S. 2006. Banks and Shareholder Value. An overview of Bank Valuation and Empirical Evidence on Shareholder value for Banks. Frankfurt: DUV Gabler Edition Wissenschaft.

Hausman, J. 1978. Specification Tests in Econometrics. Econometrica 46: 1251 
-71 .

Iqbal, A., and Kumel, O. 2014. Impact of financial crisis on firms' capital structure in UK, France, and Germany, Multinational Finance Journal 18: 249-280.

Judson, R., and Owen, A. 1999. Estimating dynamic panel data models: A guide for Macroeconomics. Economic Letters 65: 9-15.

Kaufman, G. 2004. Macroeconomic stability, bank soundness and designing optimum regulatory structures. Multinational Finance Journal 8: 141-171.

Kenourgios, D.; Christopoulos, A.; and Dimitriou, D. 2013. Asset markets contagion and the global financial crisis. Multinational Finance Journal 17: 49-76.

Kimball, R. 1998. Economic profit and performance measurement in banking. New England Economic Review, Federal Reserve of Boston issue July: 35-53.

Lee, J., and Strazicich, M. 2003. Minimum Lagrange Multiplier Unit Root Test with Two Structural Breaks. The Review of Economics and Statistics 85: 1082-1089.

Lepetit, L.; Nys, E.; Rous, P.; and Tarazi, A. 2008. Bank income structure and risk: an empirical analysis of European Banks. Journal of Banking and Finance 32: 1452-1467.

Miller, S., and Noulas, A., 1997. Portfolio mix and large-bank profitability in the USA. Applied Economics 29:505-512.

Salas, V., and Saurina, J. 2003. Deregulation, market power and risk behavior in Spanish Banks, European Economic Review 47: 1061-1075.

Xiao, Y. 2009. French banks amid the global financial crisis. International Journal of Banking and Finance 8: 1-19.

White, H., 1980. A Heteroskedasticity- Consistent covariance matrix estimator and a direct test for heteroscedasticity. Econometrica 48: 817-38.

Wooldridge, J. 2009. Introductory econometrics: A modern approach: Canada: South Western Cengage Learning. 